\title{
EFFECTIVENESS OF BYLAWS IN THE MANAGEMENT OF NATURAL RESOURCES:
}

The West African Experience

Koffi Alinon, University Mande Bukari, Bamako, Mali

Antoine Kalinganire, World Agroforestry Centre (ICRAF) 
The CGIAR Systemwide Program on Collective Action and Property Rights (CAPRi) is an initiative of the 15 centers of the Consultative Group on International

Agricultural Research (CGIAR). The initiative promotes comparative research on the role of property rights and collective action institutions in shaping the efficiency, sustainability, and equity of natural resource systems. CAPRi's Secretariat is hosted within the Environment and Production Technology Division (EPTD) of the International Food Policy Research Institute (IFPRI). CAPRi receives support from the Governments of Norway, Italy and the World Bank.

CAPRi Working Papers contain preliminary material and research results. They are circulated prior to a full peer review to stimulate discussion and critical comment. It is expected that most working papers will eventually be published in some other form and that their content may also be revised.

\section{Cite as:}

Alinon, K., Kalinganire. A. 2008. Effectiveness of bylaws in the management of natural resources: The West African experience. CAPRi Working Paper No. 93. International Food Policy Research Institute: Washington, DC. http://dx.doi.org/10.2499/CAPRiWP93

Copyright (c) December 2008. International Food Policy Research Institute. All rights reserved. Sections of this material may be reproduced for personal and not-for-profit use without the express written permission of but with acknowledgment to IFPRI. To reproduce the material contained herein for profit or commercial use requires express written permission. To obtain permission to reprint, contact the IFPRI Communications Division at ifpri-copyright@cgiar.org. 


\section{ABSTRACT}

The role of various stakeholders in the management of natural resources is not clear in the West African countries. This paper discusses the historical changes in power delegation from central origins to peripheral institutions. The analysis covers the rise of bylaws across the Western African countries and links the multiplicity of bylaws to the amplification of the decentralization movement.

On the basis of a literature review and their own practitioners' experiences, the authors demonstrate the pertinence of bylaws as a tool for better management of natural resources. In the West African Francophone context, bylaws could stand both for regulations enacted by decentralized authorities or "local conventions" binding village community groups. Where formal bylaws suffer from limited enforcement, local people continue, through their traditional representatives, to engage in the negotiation of local conventions for the management of natural resources.

According to the authors, there is a need to recognize local conventions, which offer an opportunity for decentralization to be more rooted in local situations. Through such conventions, traditional institutions prove their ability to reshape with decentralization even if decentralization reforms and national forestry laws have ignored them across West Africa.

Keywords: bylaws, West Africa, natural resource management, decentralization 


\section{ACKNOWLEDGMENTS}

We are very grateful for the institutions which have provided travel and administrative support during the preparation of this paper. We thank the World Agroforestry Centre (ICRAF), the CGIAR Systemwide Program on Collective Action and Property Rights (CAPRi), the International Development Research Centre (IDRC-Biodiversity Project), the International Fund for Agricultural Development (IFAD TAG 799 Project), and the University Mande Bukari, Bamako, Mali (UMB) for their support to both authors. The first version of this paper was presented at the Africa-wide Research Workshop on Bylaws in November 2006 in Nairobi, Kenya. Our thanks go to the participants who provided useful feedback, especially Brent Swallow and Helen Markelova. Finally, we acknowledge helpful comments from John C. Weber (ICRAF) and two anonymous reviewers. 


\section{Table of Contents}

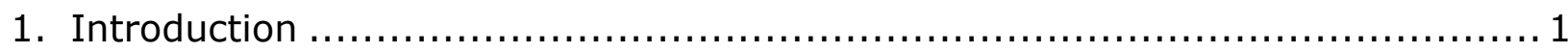

2. Bylaws and local conventions: definitions and their role in the management of

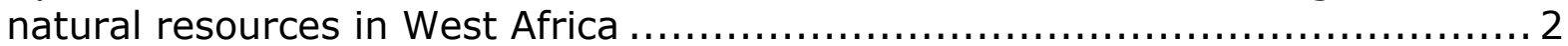

3. Comparison of past experiences in natural resources management in the West

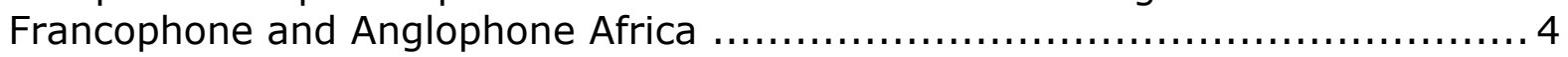

4. The decentralization process and the rise of bylaws............................. 5

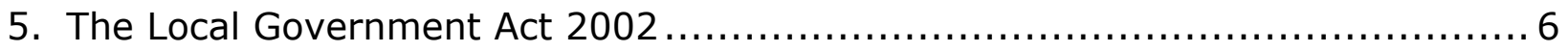

6. The balance between legality, legitimacy, and sound economic profitability ...... 7

7. Conclusions and implications for research and practice ........................... 9

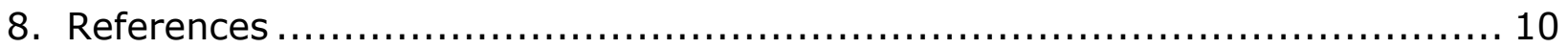




\title{
EFFECTIVENESS OF BYLAWS IN THE MANAGEMENT OF NATURAL RESOURCES:
}

\author{
The West African Experience \\ Koffi Alinon ${ }^{1}$ and Antoine Kalinganire
}

\section{INTRODUCTION}

West Africa is an environmentally diverse region that is poor, growing rapidly, and losing valuable natural resources. Most West African countries span several ecogeographical zones including the Saharan desert zone, the Sahelian arid zone, the Sudano-Sahelian semi-arid zone, the sub-humid Sudanian zone, and the humid Sudano-Guinean and Guinean zone (Niasse et al., 2004). With the exception of Ghana, Nigeria, and Côte d'Ivoire, all the West African countries are in the category of the Least Developed Countries (LDCs) (UNDP, 2000); population growth ranges from 2-3 percent per year. Natural resources are being degraded at very high rates, mainly due to several biophysical, socio-economic, and political factors (Allen and Barnes, 1985). Deforestation, for example, is driven by the demand for agricultural land. Environmental governance, including policies at the national, regional, and local level, affects the on-going changes in the management of natural resources.

There is confusion in West Africa regarding rules for access and management of land and other natural resources at the local level. The current situation is a result of a perpetual misunderstanding between pre-existing customary practices and legislative and institutional schemes inherited from Western societies. However, beyond this demarcation between public administration and traditional institutions, a tendency continues to prevail which consists of "shadow encounters" between local formal decentralized authorities and informal entities (for example, villages committees). They engage to enact rules that regulate the access and use of renewable natural resources and guarantee their peaceful utilization.

In this paper we argue that recognizing bylaws as one of the most capable arrangements in the management of natural resources at a local level is a better way to harmonize the ongoing decentralization process with local practices. Our discussion supports the idea that the most pertinent level at which natural resources must be mastered is the one where all users are at stake. Conservation initiatives starting at that level are more likely to succeed than rules and laws imposed from the top.

${ }^{1}$ Corresponding author: kof30al@yahoo.com 


\section{BYLAWS AND LOCAL CONVENTIONS: DEFINITIONS AND THEIR ROLE IN THE MANAGEMENT OF NATURAL RESOURCES IN WEST AFRICA}

It is necessary at an early stage to clarify what is understood by "bylaws" in this paper, particularly in the West African Francophone context where bylaws and "local conventions" coexist. It is difficult to find a term in French that corresponds to the English term "bylaw". A simple but workable definition comes from Nkonya et al. (2005): "Bylaws are subsidiary laws that are enacted by the local governments." In fact, the authors explain that the bodies that enact bylaws go beyond the executive sphere and comprise local councils, which have a legislative dimension. Therefore, bylaws are enacted at the local level by elected or executive institutions.

Geographically, the notion of the "local level" is variable. In general, it is lower than the national and regional levels and corresponds to the municipal and district size.

In the Francophone West Africa, municipal councils exist, and, one level higher, there is a decentralized institution representing a variable number of towns; these are called "Circle councils" (Mali), "Prefecture councils" (Togo), "Province councils" (Burkina Faso), or "Department councils" (Niger). Villages have not been considered like these decentralized entities, but village chiefs contribute to establishing rules in the management of natural resources. Decentralized bodies enact "decisions" which have to conform to the provisions in the national constitution. The representatives of the central authority (Ministry of Home Affairs), who are nominated in each of the decentralized zones, make decisions which are called "arêtes," once these are signed by the representatives. So, in the Francophone context bylaws correspond to "decisions" and "arrêtés" emanating from municipalities, circles, prefectures, provinces, and departments.

The decentralization process in Francophone West Africa is in its early stages. It started following the collapse of one-party systems in the early 1990s. To date, the state has not yet transferred control, including management of land, forestry and finance, to the local institutions. Although bylaws enacted at the local level are not published, we assume that very few of them concern natural resources management since the state maintains its right to establish rules of access to such resources.

In West Africa it is important to consider "local conventions" in the scope of bylaws, since these are becoming increasingly important for the management of natural resources. According to Dicko (2002), the term "local convention" describes all agreements between social groups in order to preserve the environment and their own interests. The German Technical Development Cooperation (GTZ, 2005), which supported a number of activities concerning those arrangements, defines local conventions as "all agreements which encompass an auto-restriction dimension in the domain of natural resources' exploitation with the objective to install compatibility between using and renewing these resources." Hilhorst and Coulibaly (1998) introduce the idea of a formal administrative dimension as a condition for validity of such conventions and consider them as a form of comanagement between villagers and representatives of the State: "a local convention is a contract between villagers and public powers in order to establish rules in the management of natural resources." According to Djire (2003), the local convention is "an agreement - written or not - between two or more local actors, namely the social groups (socio-professional groups, associations, villages 
communities or factions), the local administration (State's representatives or decentralized bodies), the technical offices and NGOs, determining rules of access and utilization of natural resources for their conservation and sustainable exploitation."

Through such conventions, traditional institutions (for example, village committees) have shown their ability to reshape with decentralization even if they had been left aside by decentralization reforms and national forestry laws across West Africa. ${ }^{2}$ There have been only few exceptions: Ly et al. (2006), for example, present a case in Niger where the forestry law recognizes traditional practices of agroforestry. The Niger code allows tree management practices, such as thinning and pruning, which favor natural regeneration of forests. In this case, the forest law is not designed for the static conservation of forests, but allows farmers and community based associations to dynamically manage and conserve agroforests in their own territory and on their farms.

When one examines the decentralization process or the modalities of enactment of formal conventions, it appears that the state delegates natural resources management only to municipalities and prefectures, departments and circles, and ignores the traditional and customary structures. But it is at the local village level where the effects of natural resource degradation are most apparent. Villagers are experiencing a situation where productive land and other natural resources are decreasing both quantitatively and qualitatively. This is why various strategies were attempted in order to regulate - and even to exclude-access to village communities' resources. However, the enactment of such local conventions is not to be considered as a sign of exclusion because all social groups dwelling in the village and considered components of the community are due to comply with the rules that were agreed upon. ${ }^{3}$

At this stage of the decentralization process, it is regrettable to note that local decentralized bodies have no resources to finance their activities apart from some donations from the State, NGOs, and international organizations. This is why the recognition by their government of their right to regulate and impose taxes and fines on the utilization of natural resources is crucial and takes on political importance.

Bylaws are important, therefore, for resource management as they constitute an arena of power negotiation between decentralized bodies and traditional institutions. In reference to the legal and institutional context of the Sahelian countries in West Africa, the local conventions did not formally correspond to bylaws. However, a paradigm shift is necessary to see the pertinence of the two types of regulation. In this regard, many local conventions serve as framework provisions for formal bylaws, and their official recognition by governments would have great impact on the management of natural resources in West Africa (Djire, 2003; GTZ, 2005).

\footnotetext{
${ }^{2}$ In Senegal, for example, the Supreme Court has denied Village Chieftaincies the ability to be considered as decentralized bodies.

${ }^{3}$ For example, forbidding the cutting of particular tree species applies to the whole village; the differences in the rights and responsibilities come into play only in situations with villagers versus transhumant populations.
} 


\section{COMPARISON OF PAST EXPERIENCES IN NATURAL RESOURCES MANAGEMENT IN THE WEST FRANCOPHONE AND ANGLOPHONE AFRICA}

There are some differences in the approach to natural resource management between the English and French speaking countries in West Africa. Such differences originate from the former colonial powers' management of their colonies (Phillips, 1989). Even though the full analysis of the indirect rule in land policy by colonial masters is beyond the scope of this paper, we will touch upon the differences in their resource governance modes. The British upheld customary land tenure and delegated enforcement powers to the chiefs on the basis of their legitimate traditional role in regulating local affairs. As the market economy grew, demand for land increased and augmented land values. Chiefs and powerful descendants then claimed their property rights on the resources by establishing evidence of their customary status as landlords. Many authors show the tendency for powerful vested actors to interpret traditional rules to their advantage and used them to favor their interests. Hobsbawn and Ranger (1983) have described this practice as an "invention of tradition." The ability of social groups to define rules and enforce certain types of rights was considerably greater in the Anglophone than in the Francophone West Africa. This was due to the practice of "indirect rule" in the English speaking countries as opposed to the French custom of direct rule over its former colonies. However, the two different approaches adopted by these two colonial powers ultimately produced the same prevalence of legal pluralism in the newly independent countries.

The philosophical values that guide the British and the French legal systems concerning land access shed some light on the previously discussed differences in governance styles. While the French civil legal system is based on the preeminence of one basic and valuable right, "droit de propriété," defines and evaluates all other rights. On the other hand, the English common law recognizes the principle of divided rights of ownership and the separation of the various rights that apply to land. Following the colonization by France and England in West Africa, these two legal systems were imposed, and customary laws were denied the status of legal

authority. In contrast to the French law, the British common law has always allowed the opportunity for local rules to regulate practices in certain circumstances.

However, we must acknowledge the possibility of manipulation by the British in some cases in Eastern Africa as noted by McAuslan (2000): "...colonial officials used and adapted customary law to suit their own ends; customary law in fact long ago ceased to be part of traditional society and became instead part of the colonial apparatus of rule."

The transition to independence in the Anglophone West Africa altered the framework within which property rights were enforced; this concerned the lands administrated under the scope of customary law. The chiefs, victorious political leaders, and others in the power elite group attempted to redefine the rights of access but were not able to restrict the State sovereignty over land. Since then, the situation prevailing in the Anglophone countries shifted and appeared quite similar to the Francophone scheme because property rights to land and natural resources remained virtual and unsecured. Private property rights, state ownership, and communal tenure coexisted, inducing legal pluralism, but the new national governments enforced none of them effectively. Although different in their 
approaches, British and French colonial policies concerning allocation of land and natural resources in African societies eventually led to the same result:

accentuating legal pluralism (Alinon, 2005). The systems of natural resource tenure in most West African countries have undergone changes as the original forms of tenure by communities have been undermined, although not fatally, by the introduction of state or individual private property.

A brief chronological review of tenure practices points out some common features:

- Prior rules governing access to land and other natural resources appeared to be an integral part of social structure, with tenure not being separated from social relationships and land use leading to certain rights. Individual rights were the fruit of negotiation in which the local land authorities acted as referees.

- Colonization brought a radical change to this institutional arrangement. The over- centralization in the Francophone countries eliminated the power of the customary authorities and imposed new mechanisms (such as public registration) derived from the Napoleonic code (or 'code civil'). The English, on the contrary, had privileged indirect rule which mainly strengthened the customary structures in land administration but also induced confusion where local chiefs have to be created ex nihilo - the colonial administrators being able to regulate land through established chieftaincy.

- Post-colonial independent states nationalized land and tried to redefine tenure rights to bring about the development of rural areas.

All of these different norms co-exist to date. People use the traditional system to acquire land and to access resources such as agroforests, forests, and pastures. Thereafter, land title is obtained through modern law, by then adding more alternatives in putting natural resources into use. The decentralization process intends to give resource management back to the elected local institutions. We believe that the bylaws generated by these institutions are an opportunity that could help to develop a workable natural resources management scheme.

\section{THE DECENTRALIZATION PROCESS AND THE RISE OF BYLAWS}

Bylaws cannot operate without local bodies which have the ability to ratify them. If we consider the institutional origin of bylaws, we can say that bylaws ratified by decentralized authorities started to become important with the creation of rural and urban municipalities and local governments following the decentralization movement by the West African states (see Table 1 for details).

The decentralization process is still in its early stages. It has moved rapidly compared to the democratization of most political regimes in the 1990s. The decentralization process across the Francophone and Anglophone countries in West Africa is summarized in Table 1. 
Table 1: Decentralization process in West Africa

\begin{tabular}{|c|c|c|c|}
\hline County & $\begin{array}{c}\text { Year of } \\
\text { Decentralization }\end{array}$ & Decree name and no. & Observations \\
\hline Benin & January 15, 1999 & $\begin{array}{l}\text { «Loi No } 97-028 \text { portant } \\
\text { organisation de l'Administration } \\
\text { Territoriale » }\end{array}$ & \\
\hline $\begin{array}{l}\text { Burkina } \\
\text { Faso }\end{array}$ & August 6, 1998 & $\begin{array}{l}\text { « Loi } N^{\circ} 040 / 98 / A N \text { portant } \\
\text { orientation de la } \\
\text { Décentralisation au Burkina » }\end{array}$ & \\
\hline $\begin{array}{l}\text { Côte } \\
\text { d'Ivoire }\end{array}$ & October 17, 1980 & 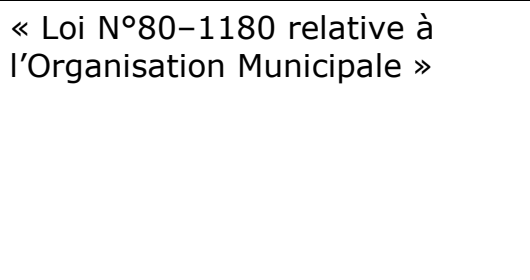 & $\begin{array}{l}\text { In } 1995 \text {, another set of } \\
\text { laws specifying the } \\
\text { domains of power } \\
\text { delegation to } \\
\text { municipalities and } \\
\text { decentralization was } \\
\text { passed. }\end{array}$ \\
\hline $\begin{array}{l}\text { The } \\
\text { Gambia }\end{array}$ & April 17, 2002 & The Local Government Act 2002 & \\
\hline Ghana & $\begin{array}{l}\text { December 24, } \\
1993\end{array}$ & Local Government Act 1993 & \\
\hline Guinea & April $21^{\text {st }} 1990$ & $\begin{array}{l}\text { «Ordonnance } \mathrm{N}^{\circ} \\
\text { 019/PRG/SGG/90 portant } \\
\text { Formation, Organisation et } \\
\text { Fonctionnement des Communes } \\
\text { en République de Guinée » }\end{array}$ & $\begin{array}{l}\text { The first legislative } \\
\text { decisions about } \\
\text { decentralization were a } \\
\text { set of ordinances in } \\
1986\end{array}$ \\
\hline Mali & February 11, 1993 & $\begin{array}{l}\text { «Loi No } 93-008 / \text { déterminant } \\
\text { les conditions de la libre } \\
\text { Administration des Collectivités } \\
\text { Territoriales» }\end{array}$ & \\
\hline Mauritania & October 20, 1987 & $\begin{array}{l}\text { «Ordonnance N० } 87-289 \\
\text { instituant les Communes » }\end{array}$ & $\begin{array}{l}\text { The political will to } \\
\text { decentralize became } \\
\text { more concrete with July } \\
1993 \text { law (Loi N93-31) }\end{array}$ \\
\hline Niger & August 10, 2001 & $\begin{array}{l}\text { « Loi N²001-23 portant } \\
\text { création de Circonscriptions } \\
\text { Administratives et de } \\
\text { Collectivités Territoriales » }\end{array}$ & \\
\hline Senegal & March 22, 1996 & $\begin{array}{l}\text { «Loi N 96-06 Portant Code } \\
\text { des Collectivités Locales» }\end{array}$ & $\begin{array}{l}\text { Senegal has been } \\
\text { decentralizing since } \\
1966 \text { (Loi No 66-64) }\end{array}$ \\
\hline Togo & February 11, 1998 & $\begin{array}{l}\text { «Loi N } 98-006 \text { portant } \\
\text { Décentralisation » }\end{array}$ & $\begin{array}{l}\text { Projected decentralized } \\
\text { bodies according to the } \\
1998 \text { law have still not } \\
\text { been formally created }\end{array}$ \\
\hline
\end{tabular}

In Senegal and Mali, many bylaws address local political and technical issues, such as electoral procedures, infrastructure supervisory measures, and so on. In some West African countries where the decentralization process has progressed more rapidly, there are texts at the local level determining principles for natural resource management. In Mali, for example, the ability of local governments to 
regulate forest access has been recognized in the provision of the Law $\mathrm{n}^{\circ} 96-50$ intended to implement the broad 1995 Forestry Law. Article 11 states:

"Decentralized territories are responsible for the management, for the organization, for the conservation and for the protection of the ecological balance of their domain." In the Ségou region of Mali, several bylaws have been annually enacted to fix periods for early bushfire, for hunting, to allow animal grazing on farms, and to determine the tree species that need to be protected.

Sow (2005) analyzed the bylaws ratified in Senegal and concluded that the decentralization offers technical mechanisms for the emergence of bylaws. He found two major factors that could accelerate the enactment of bylaws. First, individual municipalities do not have the financial resources to manage local natural resources. Secondly, the decentralization law presents a framework that allows the merging of several municipalities and the practice of inter-communality. The domain covered by the bylaws (ratified by formal decentralized bodies) is very limited as it only concerns technical matters and seems disconnected from practices on the ground. Those formal bylaws are unknown and ignored by villagers who continue to engage in the negotiation of local conventions through their traditional representatives.

Local conventions have also gained influence with the beginning of the decentralization reforms. For Djire (2003), the reinforcement of the two processes (local conventions and decentralization) is natural as the institutionalization of decentralized bodies permitted the emergence of new parties and various actors who could sign such conventions. He noted that the geographical area covered by the local conventions increased from the village limits to inter-village and regional zones.

Several aspects of natural resource management are often regulated by local conventions. Those include management of the village territory ("terroir"), use of rural infrastructures, regulation of pastures, forestry, fishing, hunting, and bushfire practices. Dicko (2002) has identified 32 local conventions being implemented in Mali. Through its projects in West Africa, the GTZ has recognized the existence of 150 local conventions (GTZ, 2005). Using local conventions as a regulation tool to better manage natural resources is then gaining popular support. But as stated earlier in the paper, the formal legal foundation of such popular agreements is weak. For us, there is room for progressive recognition of local conventions. The time has come to begin thinking about the possible interface where legality (formal legal basis) will cross legitimacy (popular acceptance of a governing regime or law as an authority) for sustainable resource use in West Africa.

\section{THE BALANCE BETWEEN LEGALITY, LEGITIMACY, AND SOUND ECONOMIC PROFITABILITY}

The legality of local conventions has often been questioned. The criticisms refer to the fact that the involvement of decentralized bodies as parties to these conventions is considered an unnecessary doubling of roles. For legal purists, decentralization already offers decentralized bodies the operational tools to intervene and to regulate the use of local natural resources. In fact, decentralization texts commonly include provisions that allow municipalities, circles, prefectures, departments, and provinces to designate responsibility for particular 
aspects of the natural resources management to a local entity, such as an association, private operator, or village (Dicko, 2002). Although management of natural resources is delegated to such entities, the formal bodies continue to control the utilization of such resources (Traoré, 1997).

Another concern about local conventions is the exclusion of people not originating from the same area where they were intended to be enforced. In the context of the Francophone Unitarian States, local conventions appear like "pockets of resistance" to the national unity that supposes the equality of all citizens no matter their origin, sex, and social class. Some authors are also skeptical about local convention, doubting the self-motivation of the population in freely involving themselves in the negotiation and the formulation of such conventions.

Furthermore, they consider that the involvement of the population is biased by the local civil servants and the NGOs that are promoting such conventions. Moreover, some aspects of the management of income generated by the regulatory activity (for example, taxes and fines) are questionable because effective governance schemes are often not planned to back the financial outcomes of the implementation of local conventions (Dicko, 2002).

The opinions reported above consider local conventions more than what such agreements were meant to be. The juridical influence on those criticisms is obvious as standard and "representative" format applicable to every binding legal instrument can often not be detected in the local conventions. However, we must stress that local conventions are similar to any new legal order, which is the result of confrontation and negotiation between various social forces. They could, therefore, be unfair for some social groups. Following the principle of the "social working of law" (Griffiths, 1986), local conventions operate within competing arenas of influences that attempt to influence the interpretation of the provisions in their favor.

Local conventions operate at the social baseline more so than the formal bylaws. Their legitimacy is, therefore, recognized by the stakeholders, and, in terms of peaceful enforcement, only this legitimacy matters. In situations of legal imbroglio, specialists in legal anthropology often call for reconciliation and "a correlation between legality and legitimacy, which could be materialized through various forms and occasions" (Rochegude, 2001). The practice on the ground tends progressively to bridge the gap: for example, some decentralized bodies in the Malian case are taking the provisions of local conventions as the basis for the formulation of formal bylaws (Djire, 2003).

The economic impact of bylaws is not to be neglected when it comes to addressing the problems of sustainable resource use and poverty alleviation. The benefits of enforcing such legal instruments flow from the income and the economic returns that derive from their application (fines or payments for permits). For example, decentralized bodies and local communities could earn significant revenue by applying the rules and regulations related to the access and the utilization of forestry resources. A GTZ (2005) report reveals the case of 17 rural communities in Senegal that protected about 27,000 ha of forest and sold the forest products four years later, earning 50 million FCFA (French West African francs), which is approximately US $\$ 95,000$. By achieving the balance between income generation and natural resources preservation, bylaws and particularly the local conventions contribute to meeting one of the prerequisites for natural resources sustainability. 


\section{CONCLUSIONS AND IMPLICATIONS FOR RESEARCH AND PRACTICE}

There is growing awareness in West Africa of the need to strengthen partnerships between governments and rural communities for the management of natural resources. Moreover, these changes are occurring in several dimensions. Granting people the right to manage their resources locally constitutes a starting point, which likely strengthens democracy, participation, and active empowerment of the population in the process of sustainable economic and social development. While the opportunities seem promising, it is important that we consider how bylaws can impact efforts deployed in the management of natural resources.

Generally, as stated by Swallow et al. (2006), formal authority is shifting from the national forestry agencies to decentralized multi-stakeholder communities and local user groups. Rules and prohibitions are gradually being augmented by incentive- and market-based approaches to environmental management. However, various forest and land related texts (and bylaws) in legislation in the Sahel do not sufficiently take into account the agroforestry systems within the framework of the written formal law (Ly et al., 2006).

The present situation does not favor the management of forests. Policy practices that promote better management should prioritize opportunities by which West Africa's natural resources could benefit from a suitable arrangement or framework. Positive steps are being made in the on-going decentralization of natural resource management and in the encouragement of local communities and administrative units to play an active role in the management of their own natural assets. There are also local conventions, customary practices, and regulations dealing natural resources management activities that should be acknowledged by West African governments. Lavigne-Delville (2004) reveals that: "All recent analyses in fact show that local arrangements remain very fragile unless they are given legal and administrative recognition. Even when rules are shared and recognized within the community concerned, they have no validity vis-à-vis third parties in the event of conflicts, whether these are internal to the group or external (herds passing through, encroachment by urban dwellers, charcoal-makers, and so on). At present, such recognition is entirely dependent on the goodwill of the administrative authorities or technical services, and is therefore extremely fragile."

As we demonstrated in this paper, various environmental, economic, and social outcomes are likely to arise from this recognition. There are important research issues to be addressed and reflections to be done on the best strategy by which to render local bylaws more effective, particularly in the situations where official legislation has begun to restore a place for local natural resources management. For example, in the case of Niger, there is a need to document the condition of efficiency of the forestry law at a local level in regard to the articulation between various organizations (state, chiefs, NGOs) and institutional constructions created in the last decade (lands commissions, decentralized authorities, villages committees for the management of "terroirs"). 


\section{REFERENCES}

Alinon, K. 2005. Managing the legal pluralism by finding intermediary land policy for the west francophone Africa - A comparative approach of national strategies. In Tradition and politics: Indigenous political structures and governance in Africa, Vaughan, O., ed. Trenton NJ: Africa World Press.

Allen, J. and D. Barnes. 1985. The causes of Deforestation in Developing Countries. Annals of the Association of American Geographers 75 (2):163-184.

Dicko, A.K. 2002. Les conventions locales dans la gestion des ressources naturelles au Mali. PACT Etudes $\mathrm{N}^{\circ}$ 14, Bamako: GTZ / DED.

Djiré, M. 2003. Les conventions locales, un outil de gestion durable des ressources naturelles ? Acquis et interrogations à partir d'exemples maliens, Communication au Forum Praia+9, CILSS / GTZ.

Griffiths, J. 1986. What is Legal Pluralism? Journal of Legal Pluralism 24:1-55.

GTZ. 2005. Les impacts socio-économiques de la gestion décentralisée des ressources naturelles, Eschborn, GTZ.

Hilhorst, T. and A. Coulibaly. 1998. Une convention locale pour la gestion participative de la brousse, London, IIED Dossier Zones Arides N 78.

Hobsbawn, E. and T. Ranger. 1983. The Invention of Tradition. Cambridge, UK: Cambridge University Press.

Lavigne-Delville, Ph., Ouedraogo, H., and C. Toulmin. 2004. Making land rights more secure. Proceedings of the international workshop for researchers and policy makers, Ouagadougou, March 19-21, 2002, GRAF/GRET/IIED.

Ly, I., Kalinganire, A., and A. Niang. 2006. Essai d'analyse de la prise en compte des systèmes agroforestiers par les législations forestières au Sahel : cas du Burkina Faso, du mali, du Niger, et du Sénégal. ICRAF Working Paper - No. 29. Nairobi: World Agroforestry Centre.

McAuslan, P. 2000. Only the Name of the Country Changes: The Diaspora of "European" Land Law in Commonwealth Africa, in Evolving Land Rights, Policy and Tenure in Africa, Toulmin, C. and J. Quan, eds. London: DFID/IIED/NRI.

Niasse, M., Afouda, A., and A. Amani. 2004. Reducing West Africa's vulnerability to climate impacts on water resources, wetlands and desertification: Elements for a regional strategy for preparedness and adaptation. Gland, Switzerland and Cambridge, UK: IUCN.

Nkonya, E., Pender, J., Kato, E., Mugarura, S., and J. Muwonge. 2005. Who knows, who cares? Determinants of enactment, awareness and compliance with community natural resources management bylaws in Uganda. CAPRI Working Paper \# 43. Washington, DC: IFPRI.

Phillips, A. 1989. The Enigma of Colonialism: British Policy in West Africa. London: Currey.

Rochegude, A. 2001. Foncier et décentralisation: Réconcilier la légalité et la légitimité des pouvoirs domaniaux et fonciers, Paris, Bulletin de Liaison du LAJP, $N^{\circ} 26$.

Sow, A. 2005. Les conventions locales: Un outil novateur de gestion des collectivités locales au Sénégal, Saint Louis, Université Gaston Berger.

Swallow, B., Russell, D., and C. Fay. 2006. Agroforestry and Environmental Governance. In World Agroforestry into the future, Garrity, D., Okono, A., Grayson, M., and S. Parroott, eds. Nairobi: World Agroforestry Centre.

Traoré, S. 1997. Les législations et les pratiques locales en matière de foncier et de gestion des ressources naturelles au Sénégal. In Développement durable au Sahel. Série Sociétés, Espaces, Temps no. 3, Tersiguel, P. and C. Becker, eds. Sociétés, Espaces, Temps, Dakar Etoile (Sénégal) et Editions Karthala, Paris (France).

UNDP. 2000. Rapport mondial sur le développement humain 2000. Paris: DeBoeck Universite. 


\section{LIST OF CAPRi WORKING PAPERS}

01 Property Rights, Collective Action and Technologies for Natural Resource Management: A Conceptual Framework, by Anna Knox, Ruth Meinzen-Dick, and Peter Hazell, October 1998.

02 Assessing the Relationships between Property Rights and Technology Adoption in Smallholder Agriculture: A Review of Issues and Empirical Methods, by Frank Place and Brent Swallow, April 2000.

03 Impact of Land Tenure and Socioeconomic Factors on Mountain Terrace Maintenance in Yemen, by A. Aw-Hassan, M. Alsanabani and A. Bamatraf, July 2000.

04 Land Tenurial Systems and the Adoption of a Mucuna Planted Fallow in the Derived Savannas of West Africa, by Victor M. Manyong and Victorin A. Houndékon, July 2000.

05 Collective Action in Space: Assessing How Collective Action Varies Across an African Landscape, by Brent M. Swallow, Justine Wangila, Woudyalew Mulatu, Onyango Okello, and Nancy McCarthy, July 2000.

06 Land Tenure and the Adoption of Agricultural Technology in Haiti, by Glenn R. Smucker, T. Anderson White, and Michael Bannister, October 2000.

07 Collective Action in Ant Control, by Helle Munk Ravnborg, Ana Milena de la Cruz, María Del Pilar Guerrero, and Olaf Westermann, October 2000.

08 CAPRi Technical Workshop on Watershed Management Institutions: A Summary Paper, by Anna Knox and Subodh Gupta, October 2000.

The Role of Tenure in the Management of Trees at the Community Level: Theoretical and Empirical Analyses from Uganda and Malawi, by Frank Place and Keijiro Otsuka November 2000.

10 Collective Action and the Intensification of Cattle-Feeding Techniques a Village Case Study in Kenya's Coast Province, by Kimberly Swallow, November 2000.

11 Collective Action, Property Rights, and Devolution of Natural Resource Management: Exchange of Knowledge and Implications for Policy, by Anna Knox and Ruth Meinzen-Dick, January 2001.

12 Land Dispute Resolution in Mozambique: Evidence and Institutions of Agroforestry Technology Adoption, by John Unruh, January 2001.

13 Between Market Failure, Policy Failure, and .Community Failure.: Property Rights, CropLivestock Conflicts and the Adoption of Sustainable Land Use Practices in the Dry Area of Sri Lanka, by Regina Birner and Hasantha Gunaweera, March 2001.

14 Land Inheritance and Schooling in Matrilineal Societies: Evidence from Sumatra, by Agnes Quisumbing and Keijuro Otsuka, May 2001.

15 Tribes, State, and Technology Adoption in Arid Land Management, Syria, by Rae, J, Arab, G., Nordblom, T., Jani, K., and Gintzburger, G., June 2001.

16 The Effects of Scales, Flows, and Filters on Property Rights and Collective Action in Watershed Management, by Brent M. Swallow, Dennis P. Garrity, and Meine van Noordwijk, July 2001.

17 Evaluating Watershed Management Projects, by John Kerr and Kimberly Chung, August 2001.

18 Rethinking Rehabilitation: Socio-Ecology of Tanks and Water Harvesting in Rajasthan, NorthWest India, by Tushaar Shah and K.V.Raju, September 2001.

19 User Participation in Watershed Management and Research, by Nancy Johnson, Helle Munk Ravnborg, Olaf Westermann, and Kirsten Probst, September 2001.

20 Collective Action for Water Harvesting Irrigation in the Lerman-Chapala Basin, Mexico, by Christopher A. Scott and Paul Silva-Ochoa, October 2001. 
21 Land Redistribution, Tenure Insecurity, and Intensity of Production: A Study of Farm Households in Southern Ethiopia, by Stein Holden and Hailu Yohannes, October 2001.

22 Legal Pluralism and Dynamic Property Rights, by Ruth Meinzen-Dick and Rajendra Pradhan, January 2002.

23 International Conference on Policy and Institutional Options for the Management of Rangelands in Dry Areas, by Tidiane Ngaido, Nancy McCarthy, and Monica Di Gregorio, January 2002.

24 Climatic Variablity and Cooperation in Rangeland Management: A Case Study From Niger, by Nancy McCarthy and Jean-Paul Vanderlinden, September 2002.

Assessing the Factors Underlying the Differences in Group Performance: Methodological Issues and Empirical Findings from the Highlands of Central Kenya, by Frank Place, Gatarwa Kariuki, Justine Wangila, Patti Kristjanson, Adolf Makauki, and Jessica Ndubi, November 2002.

26 The Importance of Social Capital in Colombian Rural Agro-Enterprises, by Nancy Johnson, Ruth Suarez, and Mark Lundy, November 2002.

Cooperation, Collective Action and Natural Resources Management in Burkina Faso: A Methodological Note, by Nancy McCarthy, Céline Dutilly-Diané, and Boureima Drabo, December 2002.

Understanding, Measuring and Utilizing Social Capital: Clarifying Concepts and Presenting a Field Application from India, by Anirudh Krishna, January 2003.

In Pursuit Of Comparable Concepts and Data, about Collective Action, by Amy Poteete And Elinor Ostrom, March 2003.

30 Methods of Consensus Building for Community Based Fisheries Management in Bangladesh and the Mekong Delta, by Parvin Sultana and Paul Thompson, May 2003.

31 Formal and Informal Systems in Support of Farmer Management of Agrobiodiversity: Some Policy Challenges to Consolidate Lessons Learned, by Marie Byström, March 2004.

32 What Do People Bring Into the Game: Experiments in the Field About Cooperation in the Commons, by Juan-Camilo Cárdenas and Elinor Ostrom, June 2004.

33 Methods for Studying Collective Action in Rural Development, by Ruth Meinzen-Dick, Monica Di Gregorio, and Nancy McCarthy, July 2004.

34 The Relationship between Collective Action and Intensification of Livestock Production: The Case of Northeastern Burkina Faso, by Nancy McCarthy, August 2004.

35 The Transformation of Property Rights in Kenya's Maasailand: Triggers and Motivations by Esther Mwangi, January 2005.

36 Farmers' Rights and Protection of Traditional Agricultural Knowledge, by Stephen B. Brush, January 2005.

37 Between Conservationism, Eco-Populism and Developmentalism - Discourses in Biodiversity Policy in Thailand and Indonesia, by Heidi Wittmer and Regina Birner, January 2005.

Collective Action for the Conservation of On-Farm Genetic Diversity in a Center of Crop Diversity: An Assessment of the Role of Traditional Farmers' Networks, by Lone B. Badstue, Mauricio R. Bellon, Julien Berthaud, Alejandro Ramírez, Dagoberto Flores, Xóchitl Juárez, and Fabiola Ramírez, May 2005.

39 Institutional Innovations Towards Gender Equity in Agrobiodiversity Management: Collective Action in Kerala, South India,, by Martina Aruna Padmanabhan, June 2005.

40 The Voracious Appetites of Public versus Private Property: A View of Intellectual Property and Biodiversity from Legal Pluralism, by Melanie G. Wiber, July 2005.

41 Who Knows, Who Cares? Determinants of Enactment, Awareness and Compliance with Community Natural Resource Management Bylaws in Uganda, by Ephraim Nkonya, John Pender, Edward Kato, Samuel Mugarura, and James Muwonge, August 2005. 
42 Localizing Demand and Supply of Environmental Services: Interactions with Property Rights, Collective Action and the Welfare of the Poor, by Brent Swallow, Ruth Meinzen-Dick, and Meine von Noordjwik, September 2005.

43 Initiatives for Rural Development through Collective Action: The Case of Household Participation in Group Activities in the Highlands of Central Kenya, By Gatarwa Kariuki and Frank Place, September 2005.

44 Are There Customary Rights to Plants? An Inquiry among the Baganda (Uganda), with Special Attention to Gender, by Patricia L. Howard and Gorettie Nabanoga, October 2005.

45 On Protecting Farmers' New Varieties: New Approaches to Rights on Collective Innovations in Plant Genetic Resources by Rene Salazar, Niels P. Louwaars, and Bert Visser, January 2006.

46 Subdividing the Commons: The Politics of Property Rights Transformation in Kenya's Maasailand, by Esther Mwangi, January 2006.

47 Biting the Bullet: How to Secure Access to Drylands Resources for Multiple Users, by Esther Mwangi and Stephan Dohrn, January 2006.

48 Property Rights and the Management of Animal Genetic Resources, by Simon Anderson and Roberta Centonze, February 2006.

49 From the Conservation of Genetic Diversity to the Promotion of Quality Foodstuff: Can the French Model of =Appellation d'Origine Contrôlée' be Exported? by Valérie Boisvert, April 2006.

50 Facilitating Collective Action and Enhancing Local Knowledge: A Herbal Medicine Case Study in Talaandig Communities, Philippines, by Herlina Hartanto and Cecil Valmores, April 2006.

51 Water, Women and Local Social Organization in the Western Kenya Highlands, by Elizabeth Were, Brent Swallow, and Jessica Roy, July 2006.

52 The Many Meanings of Collective Action: Lessons on Enhancing Gender Inclusion and Equity in Watershed Management, by Laura German, Hailemichael Taye, Sarah Charamila, Tesema Tolera, and Joseph Tanui, July 2006.

53 Decentralization and Environmental Conservation: Gender Effects from Participation in Joint Forest Management, by Arun Agrawal, Gautam Yadama, Raul Andrade, and Ajoy Bhattacharya, July 2006.

54 Improving the Effectiveness of Collective Action: Sharing Experiences from Community Forestry in Nepal, by Krishna P. Achyara and Popular Gentle, July 2006.

55 Groups, Networks, and Social Capital in the Philippine Communities, by Marie Godquin and Agnes R. Quisumbing, October 2006.

56 Collective Action in Plant Genetic Resources Management: Gendered Rules of Reputation, Trust and Reciprocity in Kerala, India, by Martina Aruna Padmanabhan, October 2006.

57 Gender and Local Floodplain Management Institutions--A case study from Bangladesh, by Parvin Sultana and Paul Thompson, October 2006.

58 Gender Differences in Mobilization for Collective Action: Case Studies of Villages in Northern Nigeria, by Saratu Abdulwahid, October 2006.

59 Gender, Social Capital and Information Exchange in Rural Uganda, by Enid Katungi, Svetlana Edmeades, and Melinda Smale, October 2006.

60 Rural Institutions and Producer Organizations in Imperfect Markets: Experiences from Producer Marketing Groups in Semi-Arid Eastern Kenya, by Bekele Shiferaw, Gideon Obare and Geoffrey Muricho, November 2006.

61 Women's Collective Action and Sustainable Water Management: Case of SEWA's Water Campaign in Gujarat, India, by Smita Mishra Panda, October 2006. 
Could Payments for Environmental Services Improve Rangeland Management in Central Asia, West Asia and North Africa? by Celine Dutilly-Diane, Nancy McCarthy, Francis Turkelboom, Adriana Bruggeman, James Tiedemann, Kenneth Street and Gianluca Serra, January 2007. Maharashtra, India, by Ravula Padmaja and Cynthia Bantilan, February 2007.

64 Gender and Collective Action: A Conceptual Framework for Analysis, by Lauren Pandolfelli, Ruth Meinzen-Dick, and Stephan Dohrn, May 2007.

Beyond Group Ranch Subdivision: Collective Action for Livestock Mobility, Ecological Viability, and Livelihoods, by Shauna BurnSilver and Esther Mwangi, June 2007.

Farmer Organization, Collective Action and Market Access in Meso-America, by Jon Hellin, Mark Lundy, and Madelon Meijer, October 2007.

Collective Action for Innovation and Small Farmer Market Access: The Papa Andina Experience, by André Devaux, Claudio Velasco, Gastón López, Thomas Bernet, Miguel Ordinola, Hernán Pico, Graham Thiele, and Douglas Horton, October 2007.

Collective Action and Marketing of Underutilized Plant Species: The Case of Minor Millets in Kolli Hills, Tamil Nadu, India, by Guillaume P. Gruère, Latha Nagarajan, and E.D.I. Oliver King, M.S. Swaminathan Research Foundation, October 2007.

70 The Role of Public-Private Partnerships and Collective Action in Ensuring Smallholder Participation in High Value Fruit and Vegetable Supply Chains, by Clare Narrod, Devesh Roy, Julius Okello, Belem Avendaño, and Karl Rich, October 2007.

Collective Action for Small-Scale Producers of Agricultural Biodiversity Products, by Froukje Kruijssen, Menno Keizer, and Alessandra Giuliani, October, 2007.

72 Farmer Groups Enterprises and the Marketing of Staple Food Commodities in Africa, by Jonathan Coulter, October 2007.

Linking Collective Action to Non-Timber Forest Product Market for Improved Local Livelihoods: Challenges and Opportunities, by Heru Komarudin, Yuliana L. Siagian, and Ngakan Putu Oka, December, 2007.

74 Collective Action Initiatives to Improve Marketing Performance: Lessons from Farmer Groups in Tanzania, by James Barham and Clarence Chitemi, March 2008.

75 Sustaining Linkages to High Value Markets through Collective Action In Uganda: The Case of the Nyabyumba Potato Farmers, by Elly Kaganzi, Shaun Ferris, James Barham, Annet Abenakyo, Pascal Sanginga, and Jemimah Njuki, March 2008.

76 Fluctuating Fortunes of a Collective Enterprise: The Case of the Agroforestry Tree Seeds Association of Lantapan (ATSAL) in the Philippines, by Delia Catacutan, Manuel Bertomeu, Lyndon Arbes, Caroline Duque, and Novie Butra, May 2008.

77 Making Market Information Services Work Better for the Poor in Uganda, by Shaun Ferris, Patrick Engoru, and Elly Kaganzi, May 2008.

78 Implications of Bulk Water Transfer on Local Water Management Institutions: A Case Study of the Melamchi Water Supply Project in Nepal, by Dhruba Pant, Madhusudan Bhattarai, and Govinda Basnet, May 2008.

79 Bridging, Linking and Bonding Social Capital in Collective Action: The Case of Kalahan Forest Reserve in the Philippines, by Ganga Ram Dahal and Krishna Prasad Adhikari, May 2008.

80 Decentralization, Pro-poor Land Policies, and Democratic Governance, by Ruth Meinzen-Dick, Monica Di Gregorio, and Stephan Dohrn, June 2008. 
81 Property Rights, Collective Action, and Poverty: The Role of Institutions for Poverty Reduction, by Monica Di Gregorio, Konrad Hagedorn, Michael Kirk, Benedikt Korf, Nancy McCarthy, Ruth Meinzen-Dick, and Brent Swallow, June 2008.

82 Collective Action and Property Rights for Poverty Reduction: A Review of Methods and Approaches, by Esther Mwangi and Helen Markelova, June 2008.

83 Collective action and vulnerability: Burial societies in rural Ethiopia, by Stefan Dercon, John Hoddinott, Pramila Krishnan, and Tassew Woldehanna, June 2008.

84 Collective Action and Vulnerability: Local and Migrant Networks in Bukidnon, Philippines, by Agnes Quisumbing, Scott McNiven, and Marie Godquin, June 2008.

85 Community Watershed Management in Semi-Arid India: The State of Collective Action and its Effects on Natural Resources and Rural Livelihoods, by Bekele Shiferaw, Tewodros Kebede, and V. Ratna Reddy, June 2008.

86 Enabling Equitable Collective Action and Policy Change for Poverty Reduction and Improved Natural Resource Management in the Eastern African Highlands, by Laura German, Waga Mazengia, Wilberforce Tirwomwe, Shenkut Ayele, Joseph Tanui, Simon Nyangas, Leulseged Begashaw, Hailemichael Taye, Zenebe Admassu, Mesfin Tsegaye, Francis Alinyo, Ashenafi Mekonnen, Kassahun Aberra, Awadh Chemangei, William Cheptegei, Tessema Tolera, Zewude Jote, and Kiflu Bedane, June 2008.

87 The Transformation of the Afar Commons in Ethiopia: State Coercion, Diversification, and Property Rights Change among Pastoralists, by Bekele Hundie and Martina Padmanabhan, June 2008.

88 Unmaking the Commons: Collective Action, Property Rights, and Resource Appropriation among (Agro-) Pastoralists in Eastern Ethiopia, by Fekadu Beyene and Benedikt Korf, June 2008.

89 Escaping Poverty Traps? Collective Action and Property Rights in Post-War Rural Cambodia, by Anne Weingart and Michael Kirk, June 2008.

90 Collective Action to Secure Property Rights for the Poor - A Case Study in Jambi Province, Indonesia, by Heru Komarudin, Yuliana Sigian, and Carol Colfer, June 2008.

91 Land Tenure in Ethiopia: Continuity and Change, Shifting Rulers, and the Quest For State Control, by Wibke Crewett, Ayalneh Bogale, and Benedikt Korf. September 2008.

92 Forest Incomes after Uganda's Forest Sector Reform: Are the Rural Poor Gaining? by Pamela Jagger. December 2008. 